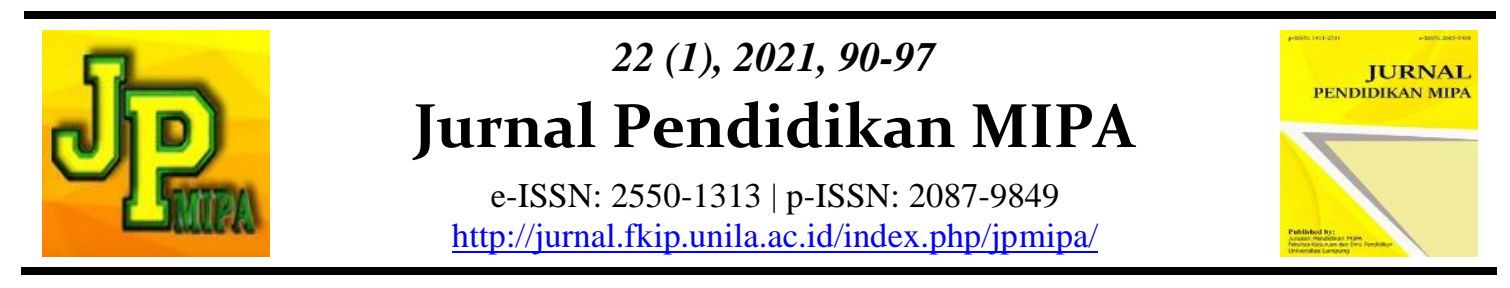

\title{
The Effect of CORE Learning Model towards Students' Mathematical Reflective Thinking Skills: A Meta Analysis Study
}

\author{
Raisa Adira Syofitami, Sri Hatuti Noer \\ Department of Mathematics Education, Universitas Lampung, Indonesia
}

\begin{abstract}
This study aims to re-analyze the CORE type of cooperative learning model related to students' mathematical reflective thinking abilities. The CORE model consists of four stages, namely Connecting, Organizing, Reflecting and Extending. In this study, researchers used the meta-analysis method. First, the researcher formulates the research problem, then proceeds to explore existing and relevant research for analysis. Data collection techniques using non-test, namely by browsing electronic journals through Google Scholar and studying documentation in the library. From the search results obtained 6 articles from journals. Based on the results of the analysis, it turns out that the CORE type of learning model is able to have an effect on students' reflective thinking skills.
\end{abstract}

Keywords: reflective thinking, cooperative learning, CORE learning model.

Abstrak: Penelitian ini bertujuan untuk menganalisis kembali tentang model pembelajaran kooperatif tipe CORE terkait kemampuan berpikir reflektif matematis siswa. Model CORE terdiri atas empat tahap yaitu Connecting, Organizing, Reflecting dan Extending. Dalam penelitian ini peneliti menggunakan metode meta analisis. Pertama-tama, peneliti merumuskan masalah penelitian, kemudian dilanjutkan dengan menelusuri penelitian yang sudah ada dan relevan untuk dianalisis. Teknik pengumpulan data dengan menggunakan non tes yaitu dengan menelusuri jurnal elektronik melalui Google Cendekia dan studi dokumentasi diperpustakaan. Dari hasil penelusuran diperoleh 6 artikel dari jurnal. Berdasarkan hasil analisis ternyata model pembelajaran tipe CORE mampu memberikan efek terhadap kemampuan berpikir reflektif siswa.

Kata kunci: berpikir reflektif, pembelajaran kooperatif, model pembelajaran CORE.

\section{- INTRODUCTION}

Having mathematical abilities is a goal that must be achieved from the process of learning mathematics in schools, reflective thinking can be categorized as high-order mathematical thinking. The ability to think reflective is a person's ability to think that involves analytical thinking of a problem, making considerations to connect the knowledge, evaluating, and drawing conclusions. Based on the results of several relevant studies, it shows that reflective thinking makes mathematics learning become meaningful (Inoue \& Buczynski, 2011; McNaught, 2010) and help students to find problem solutions logically (Agustan et al., 2017), with reflective thinking students ${ }^{6}$ know how to express the processes are running in their minds in solving mathematics problems.

Some of the results of previous research on reflective abilities, the low ability of students to think reflective because teachers often force students' thinking to be the same as the teacher's own way of thinking so that the students' cannot improve their 
reflective thinking. Learning that takes place does not involve developing students' thinking skills so that students' reflective abilities are difficult to develop (Nindiasari et al., 2014). Therefore, learning innovation is needed that is not just providing information from the teacher and can increase activeness in learning so that students' reflective abilities can develop, so cooperative learning can be an option for creating active learning. Cooperative learning can create active learning through discussion with groups, cooperative learning is learning to consist of small groups of students who work together working as a team to solve problems, or do something to achieve a goal (Suherman, 2003). One type of cooperative learning is CORE, which is based on constructivism theory and is a learning model with a discussion method.

The CORE model aims to develop student reasoning which consists of four stages, there is Connecting, Organizing, Reflecting, Extending (Curwen et al., 2010). At the stage connecting, students are invited to be able to connect new knowledge with the knowledge they already have. Furthermore, the stage organizing, this stage can help students to organize their knowledge. The third stage, namely reflecting, in this stage students are trained to be able to explain again the information that has been obtained. The last stage is extending, which is the process of expanding knowledge, one of which is by way of discussion. The stages in CORE can be used to connect old information with new information, organize several varied materials, reflect on everything students learn in solving problems and develop their learning environment, so that the learning obtained will be more meaningful because students are not only able to solve problems but also able to express how the processes are running in their minds, therefore CORE learning can facilitate students in developing their mathematical reflective abilities. This study aims to re-analyze the CORE type of cooperative learning model towards students' mathematical reflective thinking skills.

\section{- METHOD}

The type of research used is meta-analysis. Meta-analysis is research conducted by researchers by summarizing research data, reviewing and analyzing research data from several previous research results. Research data collection is carried out by researchers by browsing articles contained in online journals, thesis or dissertation results in the repository, using Google Scholar. The keywords used by the researcher in searching the article are "CORE Type Learning Model", "Mathematical Reflective Thinking".

From a search using the keywords "CORE Type Learning Model" and "Mathematical Reflective Thinking" several articles were obtained and then selected articles that met the criteria for the CORE Type Learning Model related to Mathematical Reflective Thinking. The meta-analysis steps are, (1) Determining and studying the research topic to be carried out, (2) Finding and collecting several sources with certain topics and selecting. Literature search can be done manually or through internet sources or websites, (3) Calculating how much impact occurs with a particular model in the meta-analysis and hypothesized testing of the inferred impacts, (4) Identifying whether there are differences in the impact on the subject, (5) Draw conclusions and interpret the results of the meta-analysis research. This article provides several recommendations for teachers, researchers, learning designers, and practitioners regarding the implementation of the model. 


\section{- RESULT AND DISCUSSION}

The results of the study obtained 6 relevant articles related to the CORE type of learning model related to reflective thinking skills. Due to the limited literature review that discusses the CORE type of learning model related to mathematical reflective thinking skills, only 3 relevant articles were discussed CORE model towards Reflective in detail. The article data is processed by summarizing and determining the essence of the research results with the CORE type learning model. Then the data is reported back by means of qualitative and quantitative descriptive.

Table 1. Effect size criteria

\begin{tabular}{cc}
\hline Size & Interpretation \\
\hline $0-0.20$ & Weak Effect \\
$0.21-0,50$ & Modest Effect \\
$0.51-1,00$ & Moderate Effect \\
$>1.00$ & Strong Effect \\
\hline
\end{tabular}

Data from the analysis of journals, effect size from CORE towards mathematical reflective thinking can be seen in Table 2 .

Table 2. Effect Size CORE Model towards Mathematical Reflective Thinking

\begin{tabular}{|c|c|c|c|}
\hline No. & Journals & Effect Size & Category \\
\hline 1 & $\begin{array}{l}\text { Improvement of Reflective } \\
\text { Mathematical Thinking Ability } \\
\text { in Junior High School Students } \\
\text { with the CORE Learning } \\
\text { Model (Rachman, 2019) }\end{array}$ & $\begin{array}{l}\frac{88.09 \%-42.85 \%}{100 \%} \\
=0.45 \%\end{array}$ & Modest Effect \\
\hline 2 & $\begin{array}{l}\text { Development of Constructivist } \\
\text { CORE Learning Tools to } \\
\text { Improve Mathematical } \\
\text { Connection Ability. (Azizah et } \\
\text { al., 2012) }\end{array}$ & $\begin{array}{l}\frac{90.21 \%-53.00 \%}{100 \%} \\
=0.37 \%\end{array}$ & Modest Effect \\
\hline 3 & $\begin{array}{l}\text { Analysis of students ability on } \\
\text { creative thinking aspects in } \\
\text { terms of cognitive style in } \\
\text { mathematics learning with } \\
\text { CORE Model using } \\
\text { constructivism approach } \\
\text { (Konita et al., 2017) }\end{array}$ & $\begin{array}{l}\frac{86.33 \%-48.06 \%}{100 \%} \\
=0.38 \%\end{array}$ & Modest Effect \\
\hline 4 & $\begin{array}{l}\text { The effectiveness of the } \\
\text { pairwise grouping strategy in } \\
\text { mathematics learning in the } \\
\text { CORE model. (Retnowati \& } \\
\text { Aqiila, 2017) }\end{array}$ & $\begin{array}{l}\frac{84.31 \%-58.00 \%}{100 \%} \\
=0.26 \%\end{array}$ & Modest Effect \\
\hline
\end{tabular}




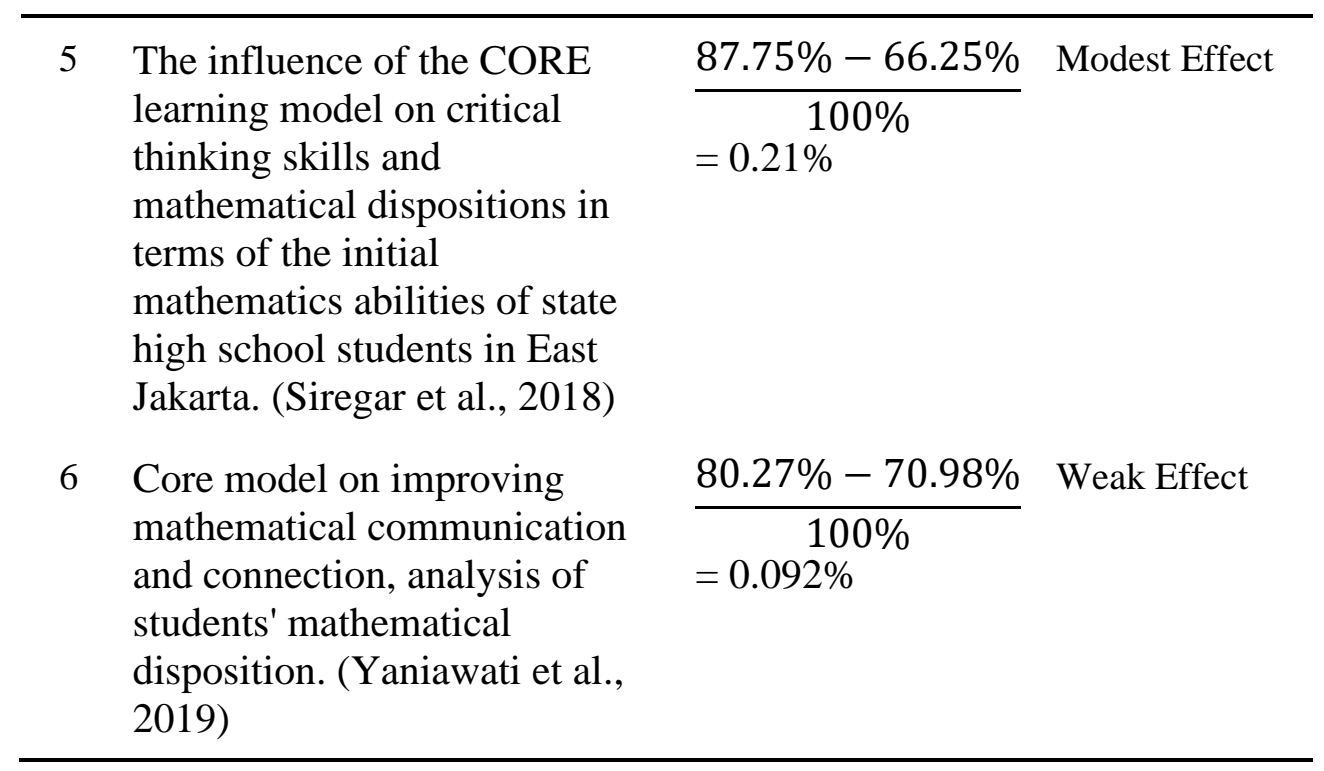

Based on Table 2. The results of the identification obtained from the 6 articles that have been selected have an effect size caused. This can be seen from the calculation in the first article in the modest effect category with an analysis result of $0.45 \%$. the calculation of the second article in the category of modest effects with $0.37 \%$ analysis results. calculation of the third article in the category of modest effects with $0.38 \%$ analysis results. the calculation of the fourth article in the modest effect category with an analysis result of $0.26 \%$. Calculation of the fifth article in the modest effect category with an analysis result of $0.21 \%$. the calculation of the sixth article in the weak effect category with an analysis result of $0.092 \%$. The results of the analysis of published articles show that there is an impact caused by the CORE type learning model on students' mathematical reflective thinking abilities. This can be seen from the articles with a total of 6 articles with a modest effect category of 5 articles and 1 article weak effect. Based on these results, it can be seen that the CORE type of learning model has an effect on students' mathematical reflective thinking abilities.

Learning type CORE model has an effect on students' mathematical reflective thinking abilities because CORE model that uses the discussion method to develop student knowledge. There are four stages in CORE learning, connecting, organizing, reflecting, and extending. The four stages are integrated with each other in learning activities. Research conducted by Rachman (Rachman, 2019) regarding the CORE learning model on mathematical reflective abilities shows positive results, students' reflective abilities in CORE learning are higher than the reflective abilities of conventional class students. In addition, (Konita et al., 2017) stated that the average student mathematics ability in the class given the CORE learning model with a constructivist approach were higher than conventional learning, especially in the creative and reflective thinking aspects.

CORE is learning that involves small groups of students discussing to be able to develop their knowledge. There are four stages in CORE learning, namely: connecting (connecting old knowledge with new knowledge), organizing (organizing various concepts/information), reflecting (explaining the information obtained), extending (expanding and developing the knowledge that has been obtained into the problem. mathematics (Retnowati \& Aqiila, 2017; Siregar et al., 2018). Based on several previous studies, related to the application of cooperative learning, especially the CORE type, 
research by Yaniawati et al. (2019) and Hafifah (2019) found that students in the class, cooperative learning especially the type CORE can provide interaction experiences between students which significantly increase, especially in connection, communication and mathematical disposition of students.

The results of the research by Azizah et al. (2012) found that the mathematical connection ability of students who used the CORE learning model with the constructivist approach was better than students who used the expository model learning and increased the value of the mathematical connection ability which was included in the moderate category. In addition, research on the type of CORE cooperative learning model can also improve reflective thinking skills, as explained Azizah et al. (2012) that the learning model CORE can make students' reflective thinking skills better. This happens because, in the phase connecting, students are invited to connect old or known information on a problem, then in the phase, organizing students are invited to process this information into a problem-solving model and solve it according to the model. After that in the phase reflecting students are invited to rethink the results of solving the problem and then invited to conclude it, therefore these phases have a lot of influence on reflective thinking skills, namely by indicators reporting, responding, relating, reasoning, and reconstructing.

CORE type learning starts from forming discussions in small groups of students about the problem of a concept to be studied. Further build the students' ideas through short questions regarding the material to be studied, so that students can connect new knowledge with previous knowledge of students. This stage will help students explore their knowledge and strengthen their mastery of the subject matter. In line with that, Cheng \& Chan (2015) stated that mathematics discussion emphasizes the interaction of people and the exchange of mathematical ideas, which is an important ability for students to present their respective mathematical concepts, understand and evaluate other students' mathematical equations and thinking.

The next stage of this learning model is organized, where students organize information related to the material that has been obtained students discuss with group members after students are able to connect the knowledge to be learned with previous knowledge and build their own knowledge. This stage also supports the improvement of mathematical reflective abilities the reacting indicator, which is to react with a personal understanding of mathematical problems by focusing on the nature of the situation.

In the next stage, Reflecting, this stage contains aspects of a contextual approach, namely reflection, students rethink or reflect on the results of their discussions with the group at the stage where organizing there are misconceptions or are correct. Students in this stage will conclude knowledge in their own language, this will show their ability to explain the information they have obtained through learning. Therefore, at this stage students can improve their reflective abilities which are formed from analytical thinking by connecting old knowledge to new knowledge and making considerations about the learning process. In line with (Sari, 2019) at the reflection stage students can rethink the process that occurs to get a concept so that mathematical reflective abilities increase, especially on indicators comparing of reflective ability, students being able to analyze and clarify individual experiences.

The last stage is Extending, where students can expand their knowledge of what has been obtained during the learning process. Expansion of knowledge can be done by using concepts that have been obtained into new situations or different contexts as the application of learned concepts, either from one concept to another, other fields of 
science, or into everyday life. At this stage, it can also improve students' mathematical reflective abilities, especially on the indicators of contemplating, that students can inform answers based on problem situations, confront answers with other answers and then reconstruct situations. (Noer, 2008). Based on the above study, with the cooperative learning type CORE, activities become more meaningful because students better understand the process they go through to get a concept, not only transferring information from the teacher, therefore the stages in CORE learning can support the improvement of students' mathematical reflective abilities.

\section{- CONCLUSION}

Based on the results and discussion of the research above, CORE type of learning model is able to have an effect on students' reflective thinking skills. The application of the CORE type of learning model related to students' mathematical reflective thinking skills is still not widely implemented, from the study of the CORE type of learning model has an effect related to students' mathematical reflective thinking skills obtained from the calculation of the effect size of 6 studies, 5 has a modest effect and 1 has a weak effect. This happened because cooperative learning type CORE involves four stages, Connecting, Organizing, Reflecting, and Extending. In these learning students can develop their reflective abilities by connecting old information with new information, organizing a variety of materials, reflecting the knowledge that has been learned in solving problems. Thus, the CORE type of cooperative learning will provide benefits for reflective thinking skills and student achievement in learning mathematics.

\section{- REFERENCES}

Agustan, S., Juniati, D., Yuli, T., \& Siswono, E. (2017). Reflective thinking in solving an algebra problem: a case study of field independent-prospective teacher Reflective thinking in solving an algebra problem: a case study of field independent-prospective teacher. Journal of Physics: Conference Series, 893(012002). 1-6

Asha, I. K., \& Al Hawi, A. M. (2016). The Impact of Cooperative Learning on Developing the Sixth Grade Students Decision-Making Skill and Academic Achievement. Journal of Education and Practice, 7(10), 60-70.

Azizah, L., Mariani, S., \& Rochmad, R. (2012). Development of Constructivist CORE Learning Tools to Improve Mathematical Connection Ability. Unnes Journal of Mathematics Education Research, 1(2). 100-105.

Cheng, Y., \& Chan, C.-M. (2015). The third level of agenda setting in contemporary China: Tracking descriptions of moral and national education (MNE) in media coverage and people's minds. International Journal of Communication, 9 (18). 1090-1107

Cumhur, F., \& Baydar, H. E. (2017). The effect of cooperative learning method in the teaching of GCD-LCM. Kastamonu Education Journal, 25(5). 18-25

Curwen, M. S., Miller, R. G., White-Smith, K. A., \& Calfee, R. C. (2010). Increasing teachers' metacognition develops students' higher learning during content area literacy instruction: Findings from the read-write cycle project. Issues in Teacher Education, 19(2), 127-151.

El Walida, S., \& Fuady, A. (2017). Level Reflective Abstraction Students In Solving Mathematics Problems. Jurnal Pendidikan Matematika (JPM), 3(2), 41-48.

Hafifah, D. N. (2019). Development of CORE Type Cooperative Learning Model 
Assistant Tutors to Improve Students' Mathematics Communication Ability .(Dissertasion Universitas Lampung). Retrieved from http://www.digilib.unila. ac.id

Haryati, T., \& Nindiasari, H. (2017). Analysis of students' mathematical reflective thinking abilities and dispositions in terms of learning styles. 10(2), 146-158.

Inoue, N., \& Buczynski, S. (2011). You asked open-ended questions, now what? Understanding the nature of stumbling blocks in teaching inquiry lessons. The Mathematics Educator, 20(2). 10-23

Johnson, D. W., Johnson, R. T., \& Smith, K. A. (2014). Cooperative learning: Improving university instruction by basing practice on validated theory. Journal on Excellence in University Teaching, 25(4), 1-26.

Konita, M., Sugiarto, S., \& Rochmad, R. (2017). Analysis of students ability on creative thinking aspects in terms of cognitive style in mathematics learning with CORE Model using constructivism approach. Unnes Journal of Mathematics Education, 6(1), 63-70.

Kramarski, B., Weiss, I., \& Sharon, S. (2013). Generic versus context-specific prompts for supporting self-regulation in mathematical problem solving among students with low or high prior knowledge. Journal of Cognitive Education and Psychology, 12(2), 197-214.

McNaught, K. (2010). Reflective writing in mathematics education programmes. Reflective Practice, 11(3), 369-379.

Metin, M., Yilmaz, G. K., Birisci, S., \& Coskun, K. (2011). The investigating high school students' learning styles with respect to the different variables: A sample from Turkey. Energy Education Science and Technology Part B: Social and Educational Studies, 3(4), 589-604.

Nindiasari, H., Kusumah, Y., Sumarmo, U., \& Sabandar, J. (2014). A metacognitive approach to improve high school students' mathematical reflective thinking skills. Jurnal Untirta 1(1). 80-90

Noer, Sri Hastuti. (2010). Peningkatan Kemampuan Berpikir kritis, Kreatif, dan Reflektif (K2R) Matematis Siswa SMP Melalui Pembelajaran Berbasis Masalah. (Dissertasion Universitas Pendidikan Indonesia). Retrieved from http://www .repository.upi.edu/8502/

Rachman, M. N. (2019). Improvement of reflective mathematical thinking Ability in SMP Students with The CORE Learning Model. (Dissertasion Universitas Pendidikan Indonesia) Retrieved from http://www.repository.upi.edu

Retnowati, E., \& Aqiila, A. (2017). The effectiveness of the pairwise grouping strategy in mathematics learning in the CORE model. Jurnal Cakrawala Pendidikan,36 (1), 13-23.

Rusman. (2016). The Development of an E-Learning-Based Learning Service for MKDP Curriculum and Learning at the Indonesia University of Education. Journal of Education and Practice, 7(31), 83-87.

Sari, E. P. (2019). Analysis of Critical Thinking Skills and Learning Outcomes of High School Students through Project Based Learning Models on Electrolite Solution Materials and Non-Electrolite Solution (Dissertasion Universitas Negeri Medan). Retrieved from http://www.eprints.umk.ac.id

Siregar, N. A. R., Deniyanti, P., \& El Hakim, L. (2018). The influence of the CORE learning model on critical thinking skills and mathematical dispositions in terms of the initial mathematics abilities of state high school students in East Jakarta. 
Jurnal Penelitian Dan Pembelajaran Matematika, 11(1). 11-23

Suherman, E. (2003). Contemporary mathematics learning strategies. Bandung: Jica.

Yaniawati, R. P., Indrawan, R., \& Setiawan, G. (2019). Core model on improving mathematical communication and connection, analysis of students' mathematical disposition. International Journal of Instruction, 12(4), 639-654. 